\title{
The significance of antinuclear and DNA antibodies in cryptogenic fibrosing alveolitis
}

\author{
ST HOLGATE, P HASLAM, M TURNER-WARWICK \\ From the Faculty of Medicine, Southampton General Hospital, and the Cardiothoracic Institute, Brompton
Hospital, London
}

ABSTRACT The roles of antinuclear and DNA antibodies in the pathogenesis of cryptogenic fibrosing alveolitis were investigated in 53 patients. Twenty-two patients who had antinuclear antibodies detected in their serum had a significantly higher proportion of women, a higher prevalence of Raynaud phenomenon and digital vasculitis, and higher erythrocyte sedimentation rates, paralleled by raised serum globulin and IgG levels, than patients with no antinuclear antibodies detected. Serum antibodies to double-strand DNA (DS-DNA), assayed by a Farr binding technique, were significantly raised in $25 \%$ of patients with cryptogenic fibrosing alveolitis. Serum binding of single-strand DNA (SS-DNA) was greatly increased in all the patients with cryptogenic fibrosing alveolitis, achieving levels similar to those found in systemic lupus erythematosus. Serum DS-DNA binding correlated with IgA levels but not with disease activity. Thus, unlike in systemic lupus erythematosus, antibodies to DS-DNA and SS-DNA with their capacity to form immune complexes are unlikely to be of major importance in the pathogenesis of cryptogenic fibrosing alveolitis.

Cryptogenic fibrosing alveolitis denotes an interstitial pulmonary disease characterised by inflammatory cell infiltration of alveoli and distortion of the lung architecture with fibrous tissue.' Since the disease is found in association with the autoimmune connective tissue diseases, ${ }^{2}$ hypergammaglobulinaemia, ${ }^{3}$. circulating non-organ-specific autoantibodies such as antinuclear antibodies and rheumatoid factors, ${ }^{4}$ and immune complexes in both serum and alveolar walls during active phases of the disease,,$^{4-7}$ an autoimmune pathogenesis has been proposed.

Immunoglobulins directed against nuclear antigens have been incriminated in the pathogenesis of systemic lupus erythematosus on the grounds that they form immune complexes which produce tissue damage by activating the complement pathway. ${ }^{8}$ Since antinuclear antibodies are also found in the sera of up to one-third of patients with cryptogenic fibrosing alveolitis, ${ }^{4}$ this study was designed to assess the prevalence and clinical associations of circulating antinuclear, double-strand DNA (DS-DNA), and single-strand DNA (SS-DNA) antibodies in this disease.

Address for reprint requests: Dr ST Holgate, Southampton General Hospital, Southampton, Hants.

\section{Methods}

We studied 53 patients who were referred to the Brompton Hospital with clinical, radiological, and physiological evidence of cryptogenic fibrosing alveolitis (table 1). Twenty patients had open lung biopsies for confirmation of the diagnosis. Patients were selected on the basis of whether or not antinuclear antibodies were detected in their serum. Fifty normal volunteer blood donors similar in sex and age range to the patients with cryptogenic fibrosing alveolitis (mean age \pm 1 SD $53 \pm 11$ years) were used as controls. Thirty-three patients (six men and 27 women, mean age $31 \pm 15$ years) who conformed to the American Rheumatism Criteria for the diagnosis of systemic lupus erythematosus ${ }^{9}$ were also studied.

Blood samples were obtained at the first hospital visit and the serum was separated at $4^{\circ} \mathrm{C}$ and stored at $-20^{\circ} \mathrm{C}$. Antinuclear antibodies were detected and titrated by double-layer immunofluorescence ${ }^{4}$; rheumatoid factors by sheep cell agglutination ${ }^{10}$; and immunoglobulins, $\operatorname{IgG}, \operatorname{IgM}$, and $\operatorname{IgA}$, by immunodiffusion. DNA antibodies were measured as the capacity of serum to bind ${ }^{3} \mathrm{H}$-actinomycinlabelled DS-DNA or SS-DNA, a Farr binding technique modified by Young " being used to 
Table 1 Clinical features of patients with cryptogenic fibrosing alveolitis positive and negative for serum antinuclear antibody (ANA)

\begin{tabular}{|c|c|c|c|}
\hline & ANA positive & ANA negative & Significance ( $p)$ \\
\hline $\begin{array}{l}\text { Age }\left(\mathrm{y}^{*}\right) \\
\text { Sex }(\mathrm{M}: \mathrm{F}) \\
\text { Length of history }\left(\mathrm{y}^{*}\right) \\
\text { Raynaud phenomenon or vasculitis }(\%) \\
\text { Arthritis or arthralgia }(\%) \\
\text { Clubbing }(\%) \\
\text { ESR }>25 \mathrm{~mm} \text { in } 1 \mathrm{~h}(\%) \\
\text { Forced vital capacity }\left(\% \text { predicted }{ }^{*}\right) \\
\left.\text { Carbon monoxide transfer factor (\% predicted }{ }^{*}\right)\end{array}$ & $\begin{array}{l}59 \pm 9^{*} \\
1 \cdot 58: 1 \\
5 \cdot 5 \pm 4 \cdot 6 \\
19 \\
32 \\
68 \\
81 \\
69 \pm 14 \\
58 \pm 19\end{array}$ & $\begin{array}{l}57 \pm 9 \\
1 \cdot 83: 1 \\
3 \cdot 7 \pm 4 \cdot 9 \\
9 \\
24 \\
70 \\
41 \\
69 \pm 20 \\
54 \pm 19\end{array}$ & $\begin{array}{l}\text { NS } \\
<0 \cdot 05 \\
<0 \cdot 05 \\
<0 \cdot 05 \\
\text { NS } \\
\text { NS } \\
<0 \cdot 001 \\
\text { NS } \\
\text { NS }\end{array}$ \\
\hline
\end{tabular}

${ }^{*}$ Mean \pm 1 SD.

Table 2 Immunological features of patients with cryptogenic fibrosing alveolitis positive and negative for antinuclear antibody

\begin{tabular}{|c|c|c|c|}
\hline & $A N A$ positive & ANA negative & Significance $(p)$ \\
\hline $\begin{array}{l}\text { Total globulin }\left(\mathrm{g} / \mathrm{l}^{*}\right) \\
\operatorname{IgA}\left(\mathrm{g} / \mathrm{I}^{*}\right) \\
\operatorname{IgM}\left(\mathrm{g} / \mathrm{l}^{*}\right) \\
\operatorname{IgG}\left(\mathrm{g} / \mathrm{I}^{*}\right) \\
\text { DS-DNA binding }\left(\%^{*}\right) \\
\text { SS-DNA binding }\left(\%^{*}\right) \\
\text { Rheumatoid factor }(\% \text { positive })\end{array}$ & $\begin{array}{l}3 \cdot 50 \pm 0 \cdot 70^{*} \\
0 \cdot 35 \pm 0 \cdot 17 \\
0 \cdot 22 \pm 0 \cdot 18 \\
2 \cdot 16 \pm 0 \cdot 94 \\
11 \cdot 25 \pm 3 \cdot 57 \\
28 \cdot 15 \pm 7 \cdot 46 \\
26\end{array}$ & $\begin{array}{r}3 \cdot 10 \pm 0 \cdot 60 \\
0 \cdot 32 \pm 0 \cdot 19 \\
0 \cdot 20 \pm 0 \cdot 21 \\
1 \cdot 72 \pm 0 \cdot 60 \\
11 \cdot 48 \pm 3 \cdot 21 \\
26 \cdot 85 \pm 5 \cdot 59 \\
24\end{array}$ & $\begin{array}{l}<0 \cdot 001 \\
\text { NS } \\
\text { NS } \\
<0 \cdot 001 \\
\text { NS } \\
\text { NS } \\
\text { NS }\end{array}$ \\
\hline
\end{tabular}

${ }^{*}$ Mean \pm 1 SD.

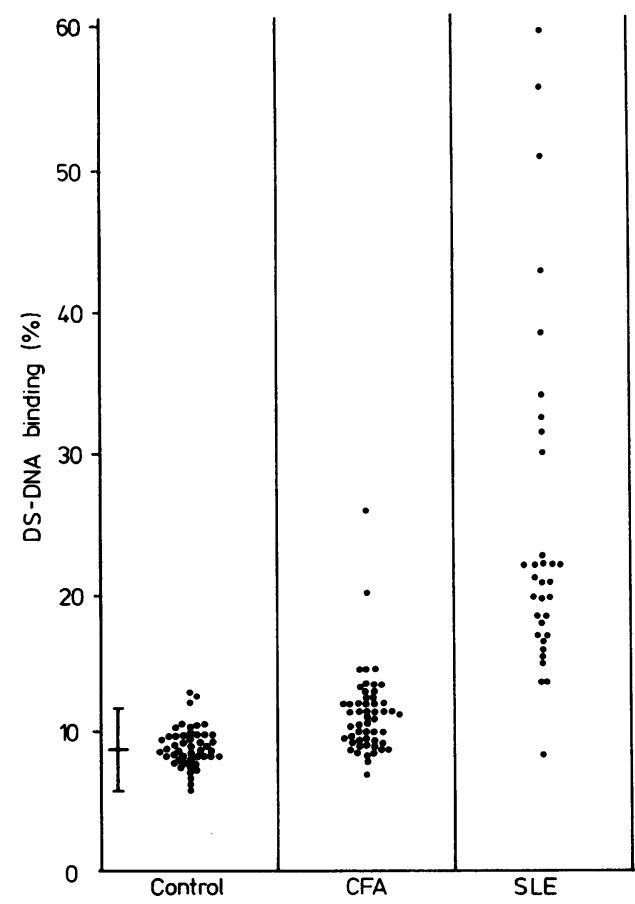

Fig 1 Double-strand DNA (DS-DNA) binding of sera from healthy normal subjects (control) and patients with cryptogenic fibrosing alveolitis (CFA) and systemic lupus erythematosus (SLE). The bars represent two standard deviations from the mean control value.

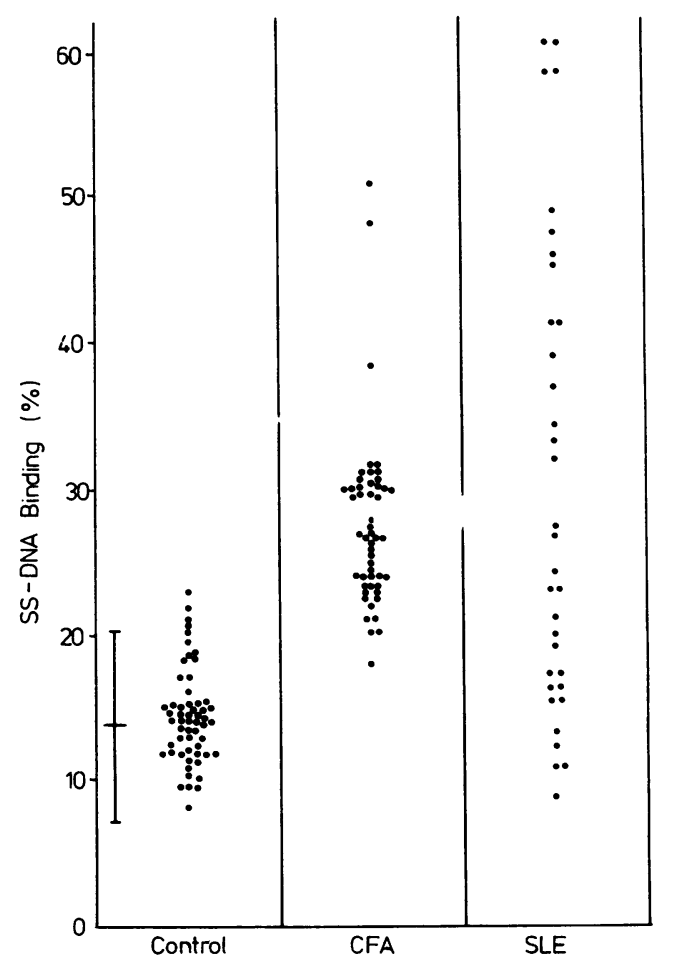

Fig 2 Single-strand DNA (SS-DNA) binding of sera from healthy normal subjects (control) and patients with cryptogenic fibrosing alveolitis (CFA) and systemic lupus erythematosus (SLE). The bars represent two standard deviations from the mean control value. 
decrease non-specific reactivity of DNA with human serum. SS-DNA was prepared by heating sonicated ${ }^{3} \mathrm{H}$-DS-DNA at $90^{\circ} \mathrm{C}$ for 10 minutes and by filtration through nitrocellulose. ${ }^{12}$ The percentage of DNA bound by serum was calculated as:

$$
\frac{\text { Precipitate }{ }^{3} \mathrm{H}-\mathrm{DNA} \mathrm{dpm}}{\text { total }{ }^{3} \mathrm{H}-\mathrm{DNA} \mathrm{dpm}} \times 100 .
$$

Student's non-paired $t$ test was used to test differences between groups and correlations were analysed by linear regression.

\section{Results}

\section{Antinuclear antibodies}

Twenty-two patients had antinuclear antibodies detected in their serum with titres of $1 / 10(8), 1 / 20(6)$, $1 / 40(2), 1 / 80$ (3), and $1 / 640$ (3). This group contained more women than the group with no antinuclear antibodies $(p<0.05)$, had a longer antecedent history before hospital presentation ( $p<0.05)$, an increased prevalence of Raynaud phenomenon and digital vasculitis $(p<0.05)$, and higher values for the erythrocyte sedimentation rate $(p<0.05)$, corresponding to increased serum total globulin and IgG levels $(\mathrm{p}<0.001)$ (table 2$)$.

\section{DNA antibodies}

Serum DS-DNA binding values of normal subjects and patients with systemic lupus erythematosus and cryptogenic fibrosing alveolitis are compared in figure 1. Thirteen of the combined groups of patients with cryptogenic fibrosing alveolitis had DS-DNA binding levels outside two standard deviations of the normal range, the mean value of $11.4 \pm 3.3 \%$ differing significantly from that of the normal control group $(9 \cdot 0 \pm 1.4 \%)(p<0.001)$. No significant difference was found in DS-DNA binding between those patients with and those without antinuclear antibodies (table 2 ). In all the patients with cryptogenic fibrosing alveolitis values for Sij-DNA binding were outside two standard deviations of the normal range (mean $27.4 \pm 6.4 \%$ ) (fig 2). In those patients with serum antinuclear antibodies SS-DNA binding of the serum correlated with the titre of antinuclear antibodies $(r=0.41, p<0.05)$. No relationship could be established between DS-DNA or SS-DNA binding and clinical features of cryptogenic fibrosing alveolitis. A positive correlation, however, was evident between serum DS-DNA binding and IgA concentration $(r=0.48, p<0.01)$, but not IgG, IgM, or titre of rheumatoid factor.

\section{Discussion}

This study identifies a subgroup of patients with cryptogenic fibrosing alveolitis who have circulating antinuclear antibodies, with a higher proportion of women, a greater prevalence of Raynaud phenomenon and digital vasculitis, higher serum globulin and IgG levels, and higher erythrocyte sedimentation rates than in patients who had no serum antinuclear antibodies detected. An association between digital vasculitis and antinuclear antibodies in patients with cryptogenic fibrosing alveolitis has been reported by Hodson et al, ${ }^{13}$ who proposed an overlap syndrome with progressive systemic sclerosis. High titres of circulating antinuclear antibodies have been described in association with immunoglobulin and $\mathrm{C} 3$ deposits in the alveolar walls during the cellular phase of the disease, but a recent retrospective study failed to show that the presence of circulating antinuclear antibodies had any prognostic value in predicting steroid responsiveness or overall survival. ${ }^{14}$

Over the last decade measurement of antibodies to double-strand DNA has proved of great value in the diagnosis and management of systemic lupus erythematosus. In our study we have found that a significant proportion of patients with cryptogenic fibrosing alveolitis also have significant increases in serum DSDNA antibody levels, which overlap with the range found in systemic lupus erythematosus (fig 1). In the latter antibodies to DNA form a major component of the circulating immune complexes, which cause tissue damage by activating the complement pathway and whose levels correlate with disease activity. ${ }^{8}$ In cryptogenic fibrosing alveolitis, however, the levels of DS-DNA antibody failed to correlate with any index of disease activity whether clinical, radiological, or physiological.

Raised levels of antibodies putatively directed against DS-DNA have also been reported in acute and chronic liver disease, ${ }^{15}$ other autoallergic diseases, ${ }^{16}$ and myasthenia gravis ${ }^{17}$ and probably reflect antibody cross-reactivity to SS-DNA determinants of the DNA preparations used in the assays. ${ }^{12}$ The serum of all the patients with cryptogenic fibrosing alveolitis had greatly enhanced binding capacity for SS-DNA, the values coming within the range observed for patients with systemic lupus erythematosus (fig 2). Haslam et $a l^{6}$ found detectable serum precipitins to SS-DNA in $33 \%$ of patients with cryptogenic fibrosing alveolitis, and a high proportion of patients whose serum contained antinuclear antibodies had enhanced lymphocyte sensitivity to exogenous commercial DS-DNA. ${ }^{18}$ In the present study SS-DNA antibodies were found in the serum of both the patients who were positive and those who were negative for antinuclear antibodies, but in the positive group a weak correlation existed between SS-DNA binding and the antibody titre. 
The significance of increased DNA antibodies in cryptogenic fibrosing alveolitis is not apparent from this investigation. Haslam et $a l^{6}$ showed only a weak correlation between the presence of precipitating antibodies to SS-DNA and the level of circulating immune complexes. Moreover, the correlation between circulating immune complexes and the serum levels of IgG found by Haslam et $\mathrm{al}^{6}$ contrasts with the correlation found in the present study between DS-DNA antibodies and IgA levels. Up to $40 \%$ of patients with cryptogenic fibrosing alveolitis have raised levels of circulating $\operatorname{Ig} \mathrm{A}^{2}$ and, since $\operatorname{IgA}$ is synthesised by lymphoid tissue associated with the respiratory tract, increased levels of this antibody class together with increased DS-DNA binding probably reflect a generalised stimulation of humoral immune activity in the lung in cryptogenic fibrosing alveolitis. Thus, unlike in systemic lupus erythematosus, circulating antibodies to DS- and SSDNA are not of central importance in the pathogenesis of cryptogenic fibrosing alveolitis and probably represent a consequence of rather than a contributory cause of the disease.

We are grateful to the clinicians of the Brompton Hospital for allowing us to study their patients. The study was supported by a grant from the Heart, Chest, and Stroke Association.

\section{References}

' Scadding JR. Lung biopsy in the diagnosis of diffuse lung disease. Br Med J 1970;ii:557-64.

${ }^{2}$ Crystal RG, Fulmer JD, Roberts WC, Moss LM, Line BR, Reynolds HY. Idiopathic pulmonary fibrosis: clinical, histologic, radiographic, physiologic, scintigraphic, cytologic, and biochemical aspects. Ann Intern Med 1976;85:769-88.

${ }^{3}$ Hobbs JR, Turner-Warwick M. Assay of circulating immunoglobulins in patients with fibrosing alveolitis. Clin Exp Immunol 1967;2:645-52.

${ }^{4}$ Turner-Warwick M. Immunological aspects of systemic disease of the lungs. Proc R Soc Med 1974;67:541-7.
${ }^{5}$ Dreisin RB, Schwarz MI, Theofilopoulos AN, Stanford RE. Circulating immune complexes in the idopathic interstitial pneumonias. N Engl J Med 1978;298:353-7.

${ }^{6}$ Haslam P, Thompson B, Mohammed I, et al. Circulating immune complexes in patients with cryptogenic $\overline{\bar{N}}$ fibrosing alveolitis. Clin Exp Immunol 1979;37:381-90.

${ }^{7}$ Eisenberg H, Simmons DH, Barnett EV. Diffuse pulmonary interstitial disease: an immunohistologic ڤ్ల study. Chest 1979;75:262-3.

${ }^{8}$ Schur PH, Sandson J. Immunologic factors and clinical. $\vec{\circ}$ activity in systemic lupus erythematosus. $N$ Engl J Med $\overrightarrow{\vec{\omega}}$ 1968;278:533-8.

${ }^{9}$ Cohen AS, Reynolds WE, Franklin EC, et al. $\stackrel{\curvearrowright}{\rightleftharpoons}$ Preliminary criteria for the classification of systemic $\times$ lupus erythematosus. Bull Rheum Dis 1971;21:643-8. W

${ }^{10}$ Rose HM, Ragan C, Pearce E, Lipman MO. Differential agglutination of normal and sensitized sheepos erythrocytes by sera of patients with rheumatoid arthritis. Proc Soc Exp Biol Med 1948;68:1-6.

"Young BJ. Detection of antibodies to DNA: studies using tritiated actinomycin D labelled DNA. Med Lab Sci 1976;33:167-72.

${ }^{12}$ Picazo JJ, Tan EM. Specificities of antibodies to native DNA. Scand J Rheum 1975;Suppl No 11:35-41.

${ }^{13}$ Hodson ME, Haslam PL, Spiro SG, Turner-Warwick M. $\vec{\bullet}$ Clinical and immunological features of patients withw cryptogenic fibrosing alveolitis and associated digital vasculitis. Thorax 1979;34:705 (abstract).

${ }^{14}$ Turner-Warwick M, Burrows B, Johnson A. Cryptogenic fibrosing alveolitis: response to corticosteriod treat-ō ment and its effect on survival. Thorax 1980;35:593-9. 유

${ }^{15}$ Kingham JGC, Rassam S, Ganguly NK, et al. DNA- $\frac{\mathbb{Q}}{\Omega}$ binding antibodies and hepatitis $B$ markers in acute and $\Rightarrow$ chronic liver disease. Clin Exp Immunol 1978;33:204-0윽 10.

${ }^{16}$ Lange A. Evaluation of the simultaneous estimation of anti dS DNA and antibodies for clinical purposes. Clin? Exp Immunol 1976;31:472-81.

${ }^{17}$ Gershwin ME, Glinski W, Bender AN, Ringel SP,으 Steinber AD, Engel WK. Antibodies to nucleic acids in myasthenia gravis. Int Arch Allergy Appl Immunolo 1976;51:245-52.

${ }^{18}$ Haslam P, Turner-Warwick M, Lukoszek A. Antinuclear antibody and lymphocyte responses to nuclear antigen in patients with lung disease. Clin Exp Immunol 1975;20:379-95. 